\title{
ПОТЕНЦАЛ КОМІКСУ ЯК МЕДІАПОВІДОМЛЕННЯ: НА ПРИКЛАДІ ТЕКСТІВ ПРО ЗБРОЙНУ АГРЕСІЮ РФ НА ДОНБАСІ («КІБОРГИ» ТА «ПЕРЕХРЕСТЯ. ДЕВ'ЯТЬ ІСТОРІЙ ПРО ВІЙНУ ТА НАСИЛЬСТВО»)
}

\author{
Світлана Хлестова \\ Харківський національний університет імені В. Н. Каразіна, \\ пл. Свободи, 4, 61000, Харків, Украӥна \\ e-mail: khlestovasveta@gmail.com \\ https://orcid.org/0000-0002-4603-499X
}

Статтю присвячено аналізу коміксу як різновиду медіаповідомлення. На прикладі «Кіборгів» та «Перехрестя. Дев’ять історій про війну і насильство» проаналізовано інформаційну функцію коміксу та його потенціал у висвітленні теми збройної агресії РФ на Донбасі. Досліджено, як документальне може поєднуватися з художнім, використання яких прийомів та 3 якою метою сприяють глибшому розумінню проблеми.

Ключові слова: масова комунікація, комікс, засіб масової комунікації, комікс-журналістика.

У сучасному світі тема війни є не лише однією 3 найболючіших, але й однією 3 найактуальніших. Останні роки тема збройного протистояння не сходить зі сторінок українських газет та випусків новин на українських телеканалах. Саме через тривалість військового конфлікту в Україні та частотність новин про нього форми медіаповідомлень стали змінюватися, аби втримати увагу аудиторії. Aкmуальність нашого дослідження обумовлена необхідністю з'ясувати можливості нетрадиційних жанрів медіа розкривати «серйозні» теми.

За визначенням У. Еко, медіаповідомлення є «комплексом знакових засобів, побудованих на основі одного або більше кодів з метою передачі певних смислів, які піддаються інтерпретації на основі цих же або інших кодів. До медіаповідомлень належать як традиційні тексти, так і тексти, побудовані за допомогою візуальних, звукових та музичних комунікативних кодів, що публікуються ЗМК та адресовані цільовій аудиторії, наприклад, новини, документальні фільми, офіційні повідомлення, прес-релізи та інше» [7].

Виходячи 3 наданого визначення, комікси можна вважати також медіаповідомленнями. Композиційно комікс має два коди для передачі смислу: текстовий та візуальний. Також комікс адресований певній цільовій аудиторії - в залежності від змісту, вона може бути дитячою, дорослою, спеціалізованою.

(C) Хлестова С., 2019

Наукове керівництво, редагування і рекомендація до друку - доц. Нечаєва Н. В. 
Мета нашої статті - вивчити потенціал коміксу про військовий конфлікт як медіаповідомлення для певної аудиторії. Предметом дослідження є коди для передачі смислу, які використовує комікс, а також його цільова аудиторія. Об'єктом є українські комікси, присвячені темі військового конфлікту на Донбасі: «Перехрестя. Дев’ять історій про війну та насильство» та серія «Кіборги».

Комікс як медіаявище досліджували М. Маклюен [4] та С. Макклауд [7]. Сформувавши уявлення про комікс, його базові характеристики й медіа потенціал, вони стверджують, що комікс як медіаповідомлення передає не лише певний набір фактів, а також є джерелом актуальної суспільно значущої інформації.

Уперше форму коміксу для повідомлення суспільно значущої інформації використав журналіст Джо Сакко. У 1996 році він видав серію репортажів про Палестину. За словами самого Сакко, саме той момент, коли він вирушив на Середній Схід і написав серію коміксів «Палестина», став відправною точкою для поєднання журналістики і коміксів [6].

Можемо стверджувати, що комікс сприймається аудиторією як частина масової культури - через надпопулярність супергеройських серій, крім того, часто комікси розміщують на останніх - «розважальних» - шпальтах газет. 3 появою «Палестини» комікс почали сприймати як засіб донесення серйозної інформації візуально, який може використовувати журналістську функцію інформування. Завдяки цьому аудиторія має змогу дізнаватися про важливі події візуальною мовою. Тут важливо зауважити, що комікс, на відміну від журналістських репортажів або заміток, не лише фіксує те, що відбулося, а й допомагає явищу більш міцно та впевнено обійняти місце в історичному процесі, не лише, на наш погляд, повідомляючи про подію, а й насичуючи їі художніми деталями.

Ідею розповідати про військовий конфлікт засобами коміксу Арт Шпігельман, творець коміксу про Холокост «Маус», прокоментував так: «У світі, де Photoshop надав можливість фальсифікувати фотознімки, відтепер можна дозволити художникам повернутися до їхньої первісної функції репортерів» [8]. Творець «Палестини» Джо Сакко так пояснив нові можливості коміксу: «Існує мало фотознімків, які фіксують точний момент: юнака, що убитий у громадянській війні в Іспанії, підозрюваного у Вьєтконзі, який застрелив начальника поліції Сайгона... Малюючи, завжди можна зафіксувати цей момент - найважливіший у тій чи іншій історії» [6].

3 погляду медіа виконання, «Гардіан» назває «Палестину» Джо Сакко першим коміксом-аналогом військового репортажу [8]. Джо Сакко є дипломованим журналістом, практикуючим автором, для якого, як він сам зазначив у інтерв'ю Believer magazine, було принципово дотримуватися журналістських стандартів та певного рівня документальності при створенні коміксу, при чому ця достовірність була критикована коміксистами як така, що порушує чистоту жанру. [6].

Серія коміксів «Кіборги» і збірник графічних новел «Перехрестя: Дев’ять історій про війну і насильство» привернули нашу увагу тому, що вони представляють собою художню фіксацію в репортерській манері збройної агресії РФ на Сході України. Обидві збірки створені на основі спогадів учасників подій, що робить їх достатньо достовірними у сприйнятті військового конфлікту.

Аналізовані тут українські комікси про Донбас - це художня інтерпретація, відображення того, що відбулося з героями через призму не лише часу, який уже минув, а й погляду художника. 
«Під час реабілітації хлопці, які повернулися з Донбасу, почали розповідати медикам історії про Донецький аеропорт: як це все було, як починалося. Один із лікарів почав записувати їх історії й шукати форму, як їх оформити. Він обрав комікси. Чому комікси? Тому що комікси - це історія про супергероїв, а кіборги - це також супергерої», - так прокоментувала історію появи «Кіборгів» представниця громадської організації «Вірні традиціям» Наталка Федечко [2].

Перший випуск «Кіборги. Початок. Том I» присвячений подіям 26 травня 2014 року - дня, коли бойовики ДНР здійснили спробу захопити будівлю стратегічного об’єкта, який у той час знаходився під охороною підрозділів 3-го полку спецпризначення (Кіровоград), а також подіям, які передували цьому. Ілюстрування та редагування коміксу здійснював львівський художник Левко Квіт. Громадська організація «Вірні традиціям», яка займається створенням цього проекту, акцентує на намаганні «досягти максимальної документальності оповіді» [3].

Якщо порівняти українських «Кіборгів» 3 близькою їм за жанром та формою «Палестиною», можна побачити різницю в поданні інформації. У «Палестині» розповідь ведеться від першої особи: автор є учасником того, що відбувається, він документує те, що бачить та чує, але його твердження, його думки та почуття відображені на сторінках коміксу - він малює їх, розміщує, у т.ч. й у вигляді коментарів і т. п. Він намагається бути об'єктивним, проте читач розуміє, яка інформація і як надходить авторові. У «Кіборгах» розповідь будується по-іншому: автор малює історію, яку йому переказав безпосередній учасник події, але робить це від третьої особи. Тобто рефлексія учасника стає вторинною по відношенню до тексту, хоча й формує його сюжетно-емоційне тло.

Фактично, документальність «Кіборгів» є умовною: учасник захисту аеропорту розповідає про подію, художник її візуалізує, а читач зчитує розповідь одночасно візуально й текстово. Участь третьої особи посередника між оповідачем і читачем не сприймається свідомістю реципієнта: вона прихована в анотації коміксу в рядку, де вказаний ілюстратор, проте, безумовно, його особисте сприйняття у цьому ланцюгу є дуже важливим, адже він розповідає не про те, що бачив, а про те, що почув і відчув.

Документальність описуваних у «Кіборгах» подій підкреслено експозиційною вставкою. На наш погляд, це важливо принаймні з двох причин. По-перше, документальність нагадує читачеві хронологію відображуваних подій, пояснює, як саме розпочалась війна на Донбасі, виокремлює найважливіші події, які стали ії причиною. По-друге, комікс, на наш погляд, буде існувати у формі документально-художнього твору довше, ніж інформаційні репортажі та замітки - саме через його художню цінність, тож його достовірність, попри художню реалізацію, $є$ концептуальною характеристикою.

Перший розворот твору виглядає так: у кадрі - уламки розбитого скла. На найбільших із них - події, важливі для розповіді про російську агресію на території України: розпочинаючи з 27 лютого, коли у Криму з'явилися «зелені чоловічки», та 1 березня 2014 року, коли віддані українські військові, які не побажали здавати аеропорт «Бельбек» у Криму, співали український гімн, стоячи під дулами автоматів, закінчуючи 6 квітня - днем захоплення Донецької ОДА. Розповідь про події вкладається здебільшого у вуста дикторів новин (як українських, так і російських). Так стала очевидна різниця в роботі мас-медіа обох країн. 
Стилістично «Кіборги» наслідують традиції супергеройських коміксів, тому фактаж подій і героїв гіперболізується художником на догоду художньо-імпресивному впливу на читача. Головні герої змальовані з реальних українських військових, однак художник підкреслює їхню відвагу й мужність, робить їх схожими на супергероїв. При цьому одного головного протагоніста - позитивного героя, як зазвичай у коміксах про супергероїв, таких як «Людина-павук», «Аквамен», «Бетмен» і т.п., тут немає: всі українські військові намальовані дуже схожими, найчастіше відрізнити їх можна завдяки нашивці з позивним. Проте кожен із героїв наділений мужніми рисами: спортивною статурою, вольовими вилицями, відважним поглядом.

Мужність як риса характеру підкреслюється не лише портретно, вона може виявлятися у вчинках: готовності служити на нижчій посаді (майор з позивним «Турист» поїхав служити радистом), або в тексті відтворюється момент, коли «кіборги» вже охороняють територію аеропорту, але бойові дії ще не розпочалися: військовий 3 позивним «Скаут» нарікає, що хлопці змушені чергувати, коли інших уже перекинули на бойові позиції. Художник підкреслив збуджений емоційний стан героя зображенням кулака крупним планом та реплікою: «Набридло чекати!».

Демонстрація сильних рук, зі зброєю, які символізують мужність військових, надалі часто використовується автором у коміксі: в епізоді, коли до аеропорту перший раз приїжджає сепаратистський батальйон «Восток», «кіборгам» вдається залякати їх, змусити піти ні з чим. При цьому спочатку автор протиставляє кадри з численними бойовиками у кузові машини та поодинокими кіборгами зі зброєю в руках, які готові відбити атаку. I вже на наступному розвороті використовується прийом 3 крупним планом: один із військових лише бере до рук гранату. Спочатку ми бачимо кіборга крупним планом, але лише силует - це повинно демонструвати, що таку ж мужність міг би виразити будь-хто з українських військових. Потім - крупний план: 3 гранати висмикується чека, третій кадр - вона вже на пальці. І це дійсно лякає ворогів - вони змушені поїхати.

Щодо вигляду антагоністів - «ворогів», слід зауважити, що бойовики зображені схематично: їх непривабливі риси обличчя, пози і міміка одноманітно агресивні. Чужинність бойовиків передається візуально - вони виділяються серед зображуваних місцевих жителів Донбасу: у них інші риси обличчя, інший одяг. Щоб акцентувати на належності бойовиків до певної національності, автор просто вкладає у вуста одного з них: «Чечня». Чужинність передається мовно: вони розмовляють російською, але автор передає мовлення українськими літерами. Наприклад: «Рассєя нам поможет! Батальон «Васток» с намі». Це створює ще одну рису, яка розділяє протагоністів та антагоністів, підсилює опозицію «свої» - «чужі», яка, зазвичай, дуже типова для супергеройських творів.

Крім того, в «Кіборгах» широко використовуються типові для супергеройських коміксів прийоми: звуконаслідування, гра тіней, кольористика. Наприклад, коли автор зображує український військовий літак, він змальований дуже маленьким, займає лише невеликий простір у кутку кадру, проте більшу його частину займає звук, який видає літак: «Вжух». Окрім цього, на кадрах, які зображують моменти бою, часто зникає фон. Зображені лише люди та їхні репліки. Таким чином, автор зосереджує увагу читача на найважливішому, відкидаючи візуально те, що могло би його втратити пильність: мовлення стає головним, візуалізація послуговує лише для емоційного навантаження моменту. 
Серія виконана в кольорах мілітарі, також використовується сірий, пісочний, інші темні тони. Це не тільки правдоподібне зображення автором природи в певну пору року (осінь, зима - все довкола сіре; весна - превалюють зелені відтінки), але й занурення читача у військову атмосферу, адже війна - головна тема серії. Ще одне важливе кольорове рішення: змальовуючи злодіїв, автор затемнює кадри: наприклад, директор аеропорту, який намагається вигнати українських військових, поводить себе як злодій, тому його обличчя майже завжди затінене.

Таким чином, створюючи комікс «Кіборги», автори намагалися розповісти про героїзм українських військових, зробити з них супергероїв, які мають надзвичайні риси: надзвичайну мужність, надзвичайну кмітливість, надзвичайну готовність захищати Батьківщину. Вони реальні, не вигадані, а їх надзвичайні риси - це наслідок надзвичайних обставин для звичайних людей, тож автори дотримуються справжньої історії, лише з певною гіперболізацією реальних моментів 3 додаванням художньої яскравості для підсилення ефекту.

Другий аналізований комікс, який розповідає правдиві історії про тих, хто відчув на собі конфлікт на Донбасі та ситуацію в Криму, - «Перехрестя. Дев’ять історій про війну та насильство». Основним завданням автори визначили розповідь про порушення прав людини та вплив військової агресії РФ проти України і збройного конфлікту на Сході України на життя окремих людей і на суспільство в цілому. Жанр коміксу був обраний тому, що від допомагає безпосередньо звернутися до читачів, передати те, що не можна сформулювати словами, а також пояснити складні речі без довгих текстів, утриматися від суджень і одностороннього зображення дійсності [5]. Завдяки високому рівню візуальності, читачі можуть переживати історії разом 3 героями і побачити світ їхніми очима.

Комікс складається 3 дев’яти історій, на основі біографічних інтерв’ю $з$ переселенцями, волонтерам тощо, які намалювали художник Сергій Захаров та художниця Софія Рунова. Книга видана за підтримки Міністерства закордонних справ Німеччини та організацій «Ліберко - Партнерство за права людини» та «Східноукраїнський центр громадських ініціатив».

На відміну від «Кіборгів», «Перехрестя» не наслідує традицію супергеройських творів, а має на меті розповісти історії звичайних людей, розкриваючи їхні особисті драми. На наш погляд, це не лише документування наслідків військового конфлікту на Донбасі та окупації Криму, а й важлива спроба донести до української аудиторії погляд на конфлікт і переживання людей, які були змушені покинути Донбас. Проблема несприйняття переселенців болюча для сучасної України. Візуалізація їхніх історій, розповіді реально пережиті драматичні моменти та життєві колізії допомогли авторам сприяти підвищенню толерантності до цих людей.

У сюжеті «Перехрестя» єднальна постать журналістки, яка слухає історії людей у потязі. Автори малюють оповідь на основі тих спогадів, якими поділилися учасники подій, читач сприймає її через постать журналістки, хоча й самі спогади намальовані теж від третьої особи. Захаров і Рунова не використовують колір, зосереджуючи увагу читача на деталях; промальовують обличчя та постаті героїв, розкриваючи їх особистості і через зовнішній вигляд.

Читач «Перехрестя» має можливість дізнатися про історію пересічних українців, не захоплюючись їхнім героїзмом, а ставлячи себе на їхнє місце, дізнаючись більше про те, чим загрожує військовий конфлікт для цивільного населення. Акцент 
переноситься з дії на внутрішній світ героїв - саме тому текст у цьому коміксі відіграє більш важливу роль: часто акцент переноситься на слова героїв, а не на дію. Тут майже немає сцен бійок або відкритого протистояння, тут зображені події з життя звичайних людей: те, як жінка сидить за робочим столом, коли до неї підходять представники т.зв. «ЛНР», те, як вона розмовляє по телефону з донькою тощо.

Твір містить дев'ять окремих історій, які об’єднані мотивом подорожі, візуалізованим на обкладинці графічного роману зображенням потягу. Одна $з$ героїнь коміксу, журналістка з Німеччини, відправляється зі Львова на схід України, і в дорозі - в поїздах, в автобусі - вона чує кожну з дев’яти історій.

На прикладі однієї 3 новел - Нова влада» - розглянемо композиційні особливості твору. Героїня глави «Нова влада» працювала в Луганській ОДА, вона потрапила в полон «на підвал» через відмову працювати на «Міністерство ЛНР». 3 нею журналістка знайомиться у поїзді «Київ - Костянтинівка» наприкінці попередньої історії «Особлива вечеря». Спочатку автор демонструє експозицію: проросійські мітинги в будівлі Луганської ОДА. Прихильники т.зв. «руського міру» намальовані як просто фігури, проте в деяких із них навмисно акцентовані маргінальні риси - спортивні штани, пропиті обличчя тощо. Автор змальовує момент штурму ОДА, вдаючись навіть до досить довгого коментаря, в якому розповідається про перемовини між співробітниками міліції, що мали захищати адмінбудівлю, та мітингувальниками. Окрім цього, автор демонструє, як за жінкою, яка відмовилася від служби у «Мініс-

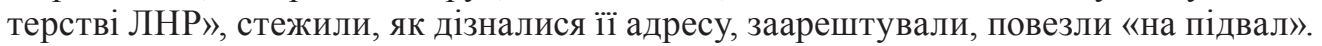

Цікавою $є$ композиція розвороту, яка демонструє перебування жінки під арештом. Підвал змальований як купольний будинок, який читач бачить згори, таким чином, демонструється середовище навколо, інші заарештовані та те, що відбувається в полоні, у т.ч. - полонені, які йдуть, очевидно, з катувань - мокрі, з перемотаними головами. Коли автор малює полон, фігури героїв зображені білими, тло - чорним. Коли героїня твору звільняється, тло стає білим. Таким чином автор підкреслює, де панує «добро», а де «зло». Наприкінці глави жінці, завдяки зусиллям її доньки, вдається втекти, а читач повертається в купе потягу, де журналістка знайомиться 3 героєм наступної новели - «Інший назавжди», бізнесменом, який теж перебував у полоні.

Важливо зазначити ще одну деталь, яка є принциповою для побудови логіки єдиного твору та єднає всі новели, пов'язує їх з реальним інформаційним полем, яке поза коміксом. Задля створення експозиції, яка б дозволила читачеві дізнатися передумови виникнення збройного конфлікту, а також основні його події, автори використовують інфографіку. Зокрема, це «Шляхи», де надають статистичну інформацію та карту України, зображають міста, в яких відбувалися події коміксу, а також «Хронологія подій», в якій за порядком вибудовано реальні події з участю реальних учасників-героїв твору.

Таким чином, можемо стверджувати, що обидва комікси є документальними розповідями про події військові дії на Донбасі, але «Кіборги» мають на меті створення позитивного образу українського військового, пропагування героїзму захисників Донецького аеропорту, цей твір рекомендований для проведення патріотично-виховної роботи. Щодо «Перехрестя» - цей комікс має на меті розповідь історій про звичайних людей, які можуть підвищити рівень толерантності, сприйняття ВПО в Україні. Окрім цього, на нашу думку, обидва твори допомагають поєднати соціаль- 
но важливу, суспільну значущу тему військового конфлікту в Україні з художньою формою, яка допоможе зберегти актуальність цих історій протягом десятиріч, коли фоторепортажі та замітки вже зникнуть у вирі інформаційного потоку.

\section{REFERENCES}

1. Кіборги: початок. Том 1 / Іл. та ред. Левко Квіт. самвидав. 40 с.: іл.

2. Коломієць А.: Кіборги: у Києві презентували комікси про українських суперменів [Електронний ресурс] / Аліна Коломієць // Український інтерес. URL: https:// uain.press/regions/kyiv/kiborgy-u-kyyevi-prezentuvaly-komiksy-pro-ukrayinskyhsupermeniv-610525

3. Комікс «Кіборги». Офіційний сайт [Електронний ресурс] / URL: https:// kiborhycomics.com.ua/

4. Маклюэн Г. М. Понимание Медиа / Пер. с англ. В. Николаева; Закл. ст. М. Вавилова. М.: Жуковский: «КАНОН-пресс-Ц», «Кучково поле», 2003. 464 с.

5. Перехресття: девять історій про війну та насильство / I. Гансен [та ін.] ; худож.оформ. С.В. Захаров, С.Ю. Рунова. К.: ГО «Східноукраїнський центр громадських ініціатив», Лібереко - Партнерство за права людини, 2017. 124 с. : іл.

6. Chute H.: An Interview with Joe Sacco [Електронный ресурс] / Hillary Chute // Believer magazine. URL: https://believermag.com/an-interview-with-joe-sacco/

7. McCloud Scott. Understanding comics: The Invisible Art. Northampton, MA: Kitchen Sink Press, 1993. 224 р. / Маклауд Скотт. Понимание комикса. Некоммерческий перевод выполнен Студи ей A7, 2011. URL: http://understanding-comics.ru/

8. Thompson D.: Eyewitness in Gaza [Електронний ресурс] / David Thompson // The Guardian. URL: https://www.theguardian.com/theobserver/2003/jan/05/comics.politics

9. Eco U. Towards a Semiotic Inquiry into Television 4.Message. Working Papers in Cultural Studies, 1965. 


\title{
THE POTENTIAL OF THE COMICS AS A MEDIA MESSAGE: ON AN EXAMPLE OF THE TEXTS ON ARMED AGGRESSION OF THE RUSSIAN FEDERATION IN THE DONBASS REGION («THE KIBORGS» AND «THE CROSSROADS. NINE STORIES ABOUT WAR AND VIOLENCE»)
}

\author{
Svitlana Khlestova \\ V. N. Karazin Kharkiv National University \\ 4 Svobody Sq., 61000, Kharkiv, Ukraine \\ e-mail: khlestovasveta@gmail.com \\ https://orcid.org/0000-0002-4603-499X
}

The paper deals with the analysis of a comics as a media message. On the example of «The Kiborgs» and «The Crossroads. Nine Stories About War and Violence» we study the informational function of the comic books and their potential in covering the theme of the military conflict. It is explored how documentary can be combined with artistry, which techniques and for what purpose can be used to provide deeper understanding of the issue. Our focus is made on the popularity of such texts in the world. We briefly outline how the phenomenon has arisen. It is our interest weather the Ukrainian creators of documentary comics follow the world tradition of documentary comics, which features of comics about the military conflict in the Donbass are used. The subject is to find out, what causes the creating comics, which combines a serious theme and an entertaining genre, to talk on military conflicts' issues.

The comic books like «The Kiborgs» and «The Crossroads. Nine Stories About War and Violence» do not just assume the informational function, reporting on what has happened. They actualize the theme, prevent it from being lost in the news stream. The artistic value of comics, which was gained due to the author's writing skills and methodology, is that it helps to capture a fragment of history mentioned in the narrative.

We compare two Ukrainian examples of comics about the war and analyze how each of them performs an informational function. In addition, we highlight other functions that perform these works. Also given a brief overview of the plots of these artworks. Real events are correlated with the fact that the author depicts on the pages of the comic.

Thus, we describe the comics about the conflict in the Donbas as a media message.

Key words: mass communication, comics, means of mass communication, comicsjournalism. 